\title{
Palladium-catalysed direct regioselective C5-arylation of a thiophene bearing a cyclopropyl ketone group at $\mathbf{C 2}$
}

\author{
Anissa Beladhria, ${ }^{\text {a,b,c }}$ Aditya L. Gottumukkala, ${ }^{\mathrm{b}}$ Chiraz Youssef, ${ }^{\mathrm{a}, \mathrm{b}}$ Charles Beromeo Bheeter, ${ }^{\mathrm{b}}$ \\ Hamed Ben Ammar, ${ }^{\text {a* }}$ Ridha Ben Salem, ${ }^{\mathrm{c}}$ Henri Doucet $^{\mathrm{b} *}$ \\ ${ }^{a}$ Laboratoire Laboratoire de Chimie Organique Appliquée, (UR 11ES74) Université de Gabès, Faculté des Sciences de Gabès, 6072 \\ Gabès, Tunisia. \\ ${ }^{b}$ Institut des Sciences Chimiques de Rennes, UMR 6226 CNRS-Université de Rennes "Organométalliques : Matériaux et Catalyse", \\ Campus de Beaulieu, 35042 Rennes, France. Fax: (+33)2-23-23-63-84 E-mail: henri.doucet@univ-rennes1.fr \\ ${ }^{c}$ Laboratoire de Chimie Organique Physique (UR 11ES74) Université de Sfax, Faculté des Sciences de Sfax, Route de la Soukra km 4 , \\ 3038 Sfax, Tunisie.
}

\begin{abstract}
A thiophene bearing a cyclopropyl ketone group at C2 was successfully employed in palladium-catalysed direct arylation. The reaction proceeds regioselectively at C5 without decomposition of the cyclopropyl ketone substituent. These couplings were performed employing as little as $0.5 \mathrm{~mol} \%$ of ligand-free $\mathrm{Pd}(\mathrm{OAc})_{2}$ catalyst with electron-deficient aryl bromides. A wide variety of functional groups on the aryl bromide such as nitrile, nitro, acetyl, formyl, benzoyl, ester, trifluoromethyl, fluoro or methoxy was tolerated. (C) 2013 Elsevier Science. All rights reserved
\end{abstract}

Keywords: palladium, C-H bond functionalization, thiophenes, cyclopropyl ketone, aryl bromides

\section{Introduction}

Thiophene derivatives are of considerable interest for pharmaceutical chemistry due to their biological activities. For example, the 2-arylthiophene derivative Canagliflozin [1] is a drug for the treatment of type 2 diabetes (Figure 1, top). Several thiophene derivatives containing an hydroxyalkyl group at $\mathrm{C} 2$ have also been found to be bioactive. Duloxetine is employed against major depressive disorder, and Tiemonium and Penthienate are antimuscarinics (Figure 1, bottom). Therefore, the development of simple and convenient processes using readily accessible thiophene derivatives for the synthesis of arylated thiophenes is highly desirable.

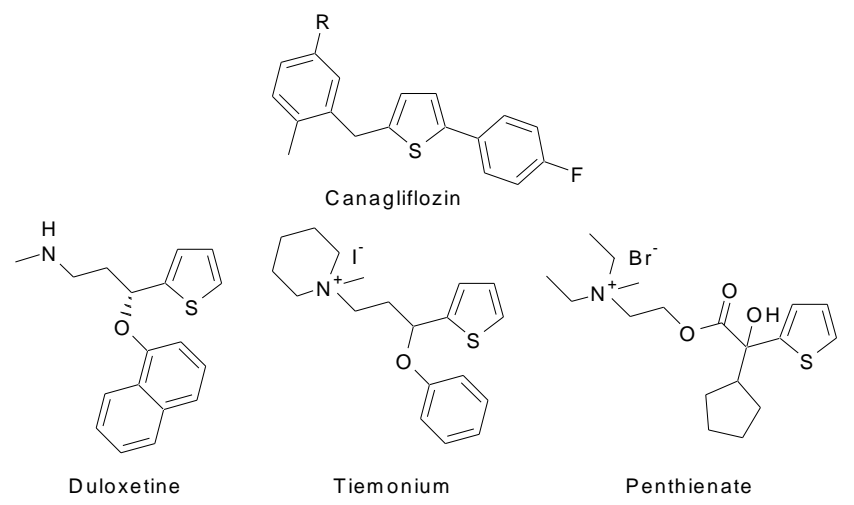

Figure 1. Examples of bioactive thiophene derivatives.

The palladium-catalyzed direct arylation of several heteroaromatics [1-12], including thiophenes, [13-16] via a C-H bond activation using aryl halides has led to successes in recent years. Such couplings are very attractive compared to classical palladium-catalysed reactions such as Stille, Suzuki or Negishi couplings,[17] as they do not require the preliminary synthesis of organometallic derivatives. However, to our knowledge, no examples of palladium catalysed direct arylation of thiophenes bearing a cyclopropyl ketone group has been described [18-24]. On the other hand, some examples of palladiumcatalysed $\mathrm{sp}^{3} \mathrm{C}-\mathrm{H}$ functionalisation of cyclopropanes have been reported $[25,26]$.

The use of such reactant for direct arylation would be very attractive for synthetic organic chemists, as cyclopropyl ketone groups on thiophene have been found to allow the synthesis of a very wide variety of thiophene derivatives (Fig. 2). Both the cyclopropyl and ketone groups can be transformed. For example, the simple reduction of the carbonyl produces the 
secondary alcool [27]; whereas, the addition of nucleophiles such as ArLi or ArMgX to the carbonyl gives the tertiary alcools [28,29]. The transformation of the carbonyl into an alkene, via a Wittig reaction, has also been described [30]. The cyclopropyle ring opening allows to prepare enones or sufonamides [31,32]. Recently, Ogoshi and co-workers have reported a [3+2] cycloaddition reaction of cyclopropyl 2-thienyl ketone with but-2-yne catalyzed by a nickel/dimethylaluminum chloride system which allow the synthesis of cyclopentenes [33]. Reactions involving both ketone and cyclopropyl groups to prepare pyrrolidine derivatives have also been described [34]. Therefore, the tolerance to such cyclopropyl ketone substituents on thiophene for palladium-catalysed direct arylations for a simple access to a variety of cyclopropyl 2-thienyl ketone derivatives needed to be studied.

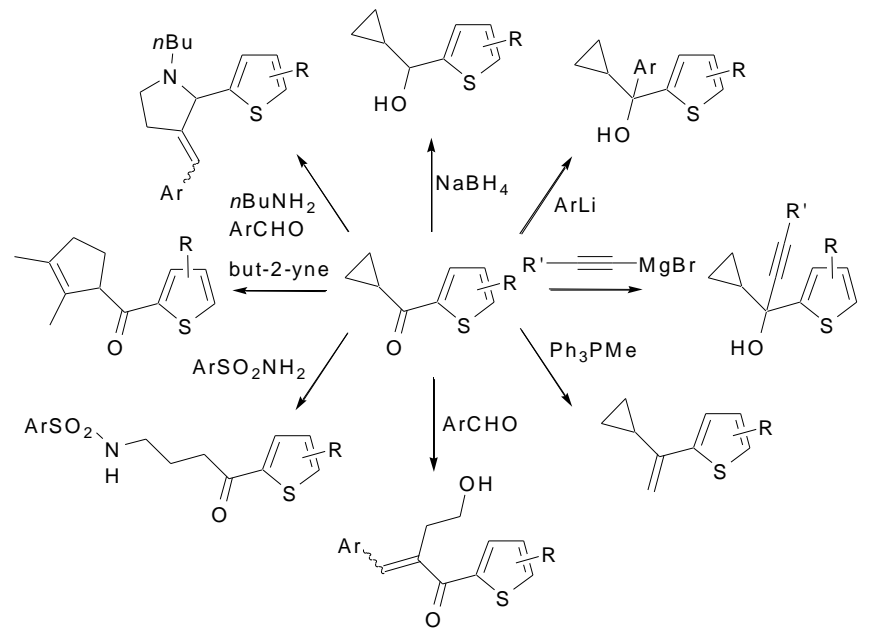

Figure 2. Reactivity of cyclopropyl 2-thienyl ketones.

Here, we wish to report (i) on the influence of the reaction conditions for the coupling of cyclopropyl 2-thienyl ketone with 4-bromoacetophenone; (ii) on the access to a wide variety of 5-arylated cyclopropyl 2-thienyl ketones using substituted aryl bromides.

\section{Results and discussion}

First, we examined the influence of the reaction conditions for the coupling of commercially available cyclopropyl 2thienyl ketone with 4-bromoacetophenone (Scheme 1, Table 1). Starting form a slight excess of cyclopropyl 2-thienyl ketone (1.5 eq.) with respect to the aryl bromide, in the presence of $0.5 \mathrm{~mol} \% \mathrm{Pd}(\mathrm{OAc})_{2}$ as the catalyst, $\mathrm{NaOAc}$ as the base, and DMA as the solvent at $120^{\circ} \mathrm{C}$, the desired product 1 was obtained in $32 \%$ yield. This moderate yield was due to a partial conversion of the aryl bromide and not to degradation of the cyclopropyl ketone substituent (Table 1, entry 1). The influence of a few other bases was then examined, and both KOAc and CsOAc, led to very high yields of $\mathbf{1}$ (Table 1, entries 2 and 3 ). On the other hand, no formation of 1 was observed in the presence of carbonates as bases (Table 1, entries 4-6). Then, we explored the influence of a few other solvents. A high yield of 1 was obtained in NPM; whereas, xylene, cyclopentyl methyl ether or pentan-1-ol were not suitable to promote this reaction (Table 1, entries 7-10). The use of 0.5 mol\% $\mathrm{PdCl}\left(\mathrm{C}_{3} \mathrm{H}_{5}\right)(\mathrm{dppb})$ catalyst at $120^{\circ} \mathrm{C}$ also produces 1 in good yield (Table 1, entry 12). Then, we reduced the catalyst loading to $0.1 \mathrm{~mol} \% \mathrm{Pd}(\mathrm{OAc})_{2}$ using both $120^{\circ} \mathrm{C}$ and $150^{\circ} \mathrm{C}$ as the reaction temperatures (Table 1, entries 13 and 14). Under these conditions, 1 was only obtained in $76 \%$ and $73 \%$ yields, although full conversions of 4-bromoacetophenone were observed, due to partial degradation of the product.

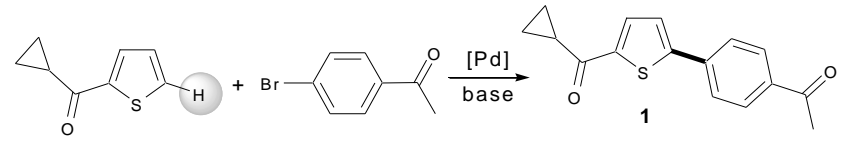

Scheme 1. Palladium-catalysed direct C5-arylation of cyclopropyl 2-thienyl ketone with 4-bromoacetophenone. 
Table 1. Influence of the reaction conditions for palladium-catalysed direct C5-arylation of cyclopropyl 2-thienyl ketone with 4bromoacetophenone (Scheme 1).

\begin{tabular}{|c|c|c|c|c|c|}
\hline Entry & $\mathrm{Pd}(\mathrm{OAc})_{2}(\mathrm{~mol} \%)$ & Solvent & Base & Conv. $(\%)$ & $\begin{array}{c}\text { Yield in } \mathbf{1} \\
(\%)\end{array}$ \\
\hline 1 & 0.5 & DMA & $\mathrm{NaOAc}$ & 38 & 32 \\
\hline 2 & 0.5 & DMA & KOAc & 100 & 89 \\
\hline 3 & 0.5 & DMA & $\mathrm{CsOAc}$ & 100 & 87 \\
\hline 4 & 0.5 & DMA & $\mathrm{K}_{2} \mathrm{CO}_{3}$ & 6 & - \\
\hline 5 & 0.5 & DMA & $\mathrm{Na}_{2} \mathrm{CO}_{3}$ & 6 & - \\
\hline 6 & 0.5 & DMA & $\mathrm{Cs}_{2} \mathrm{CO}_{3}$ & 3 & - \\
\hline 7 & 0.5 & NMP & KOAc & 100 & 78 \\
\hline 8 & 0.5 & xylene & KOAc & 0 & - \\
\hline 9 & 0.5 & cyclopentyl methyl ether & KOAc & 1 & - \\
\hline 10 & 0.5 & pentan-1-ol & KOAc & 1 & - \\
\hline 11 & 0.5 & DMA & KOAc & 100 & $85^{\mathrm{a}}$ \\
\hline 12 & 0.5 & DMA & KOAc & 100 & $84^{\mathrm{b}}$ \\
\hline 13 & 0.1 & DMA & KOAc & 100 & 76 \\
\hline 14 & 0.1 & DMA & KOAc & 100 & $73^{\mathrm{c}}$ \\
\hline
\end{tabular}

Conditions: $\mathrm{Pd}(\mathrm{OAc})_{2}, 4$-bromoacetophenone $(1 \mathrm{mmol})$, cyclopropyl 2-thienyl ketone $(1.5 \mathrm{mmol})$, base $(2 \mathrm{mmol}), 120^{\circ} \mathrm{C}, 16 \mathrm{~h}$, argon, conv. of 4-bromoacetophenone. ${ }^{\mathrm{a}}$ Cyclopropyl 2-thienyl ketone $(1 \mathrm{mmol}) .{ }^{\mathrm{b}} \mathrm{PdCl}\left(\mathrm{C}_{3} \mathrm{H}_{5}\right)(\mathrm{dppb})$ as catalyst. ${ }^{\mathrm{c}} 150^{\circ} \mathrm{C}$.

We then studied the scope of the 5-arylation of cyclopropyl 2-thienyl ketone using $0.5 \mathrm{~mol} \% \mathrm{Pd}(\mathrm{OAc})_{2}$ catalyst, KOAc as the base and DMA as the solvent at $120^{\circ} \mathrm{C}$ (Scheme 2, Tables 2-4). First, the reactivity or para-substituted aryl bromides was examined (Table 2). Good yields in 2-4 were obtained from 4-bromobenzaldehyde, 4-bromobenzophenone or methyl 4bromobenzoate (Table 2, entries 1-3). As expected, the strongly electron-withdrawing substituents, nitro or cyano at C4 of bromobenzenes were also tolerated to give 5 and $\mathbf{6}$ in $90 \%$ and $93 \%$ yields, respectively (Table 2, entries 4 and 5). On the other hand, from bromobenzenes bearing fluoro, methyl, tert-butyl or methoxy substituents at $\mathrm{C} 4$, using $0.5 \mathrm{~mol} \% \mathrm{Pd}(\mathrm{OAc})_{2}$ catalyst, conversions of 55-76\% of these aryl bromides were observed and 7-10 were isolated in only 51-68\% yields. With these more challenging substrates, $2 \mathrm{~mol} \% \mathrm{PdCl}\left(\mathrm{C}_{3} \mathrm{H}_{5}\right)(\mathrm{dppb})$ catalyst had to be employed to obtain complete conversions leading to 7-10 in slightly higher yields (Table 2, entries 6-13). Dppb ligand certainly favours the oxidative addition of these aryl bromides to palladium.

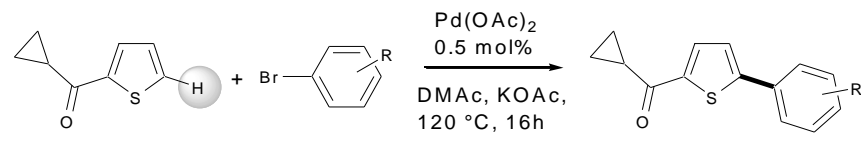

Scheme 2. Palladium-catalysed direct 5-arylation of cyclopropyl 2-thienyl ketone with (hetero)aryl bromides.

Table 2. Palladium-catalysed 5-arylation of cyclopropyl 2-thienyl ketone with para-substituted aryl bromides (Scheme 2).

Entry




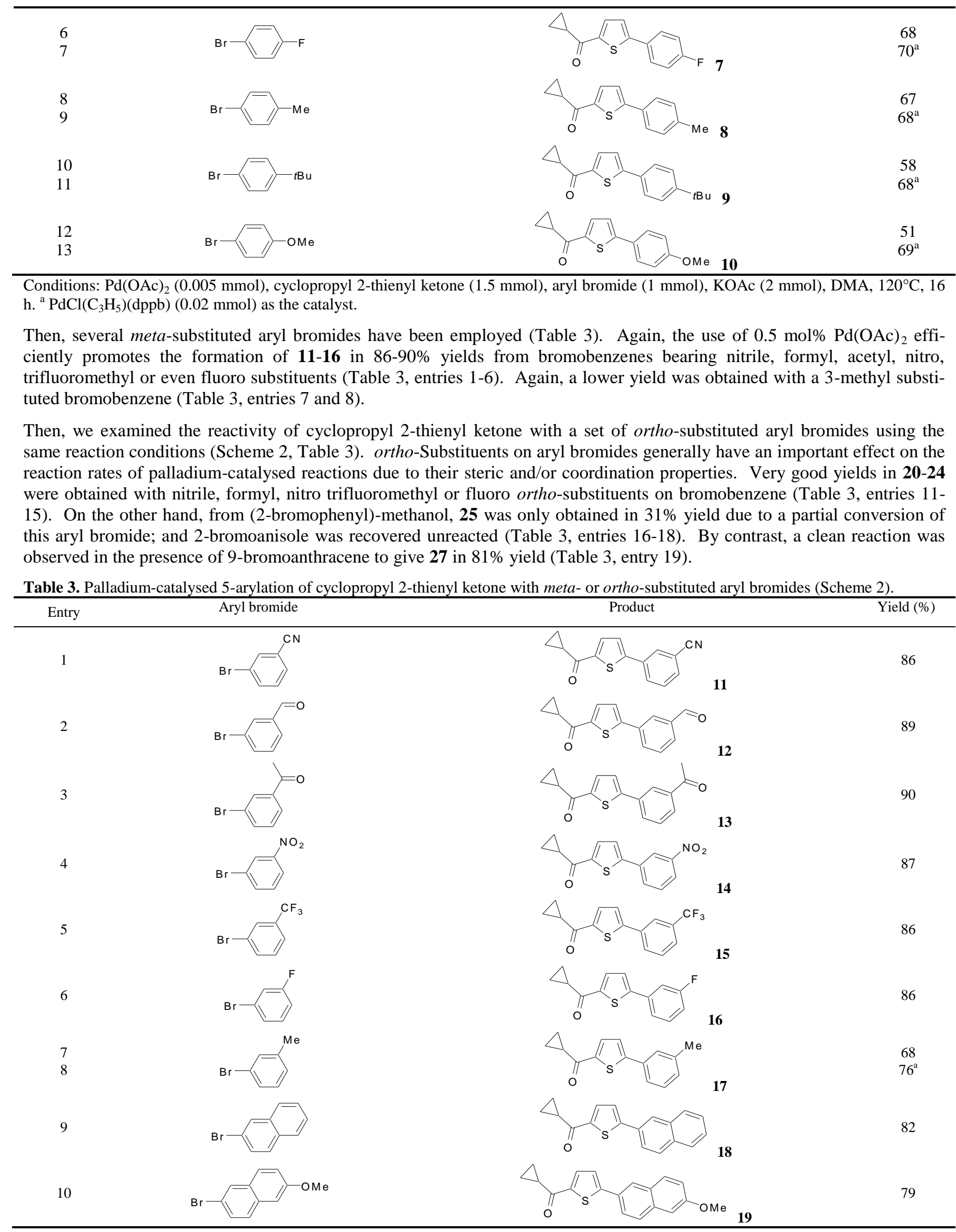




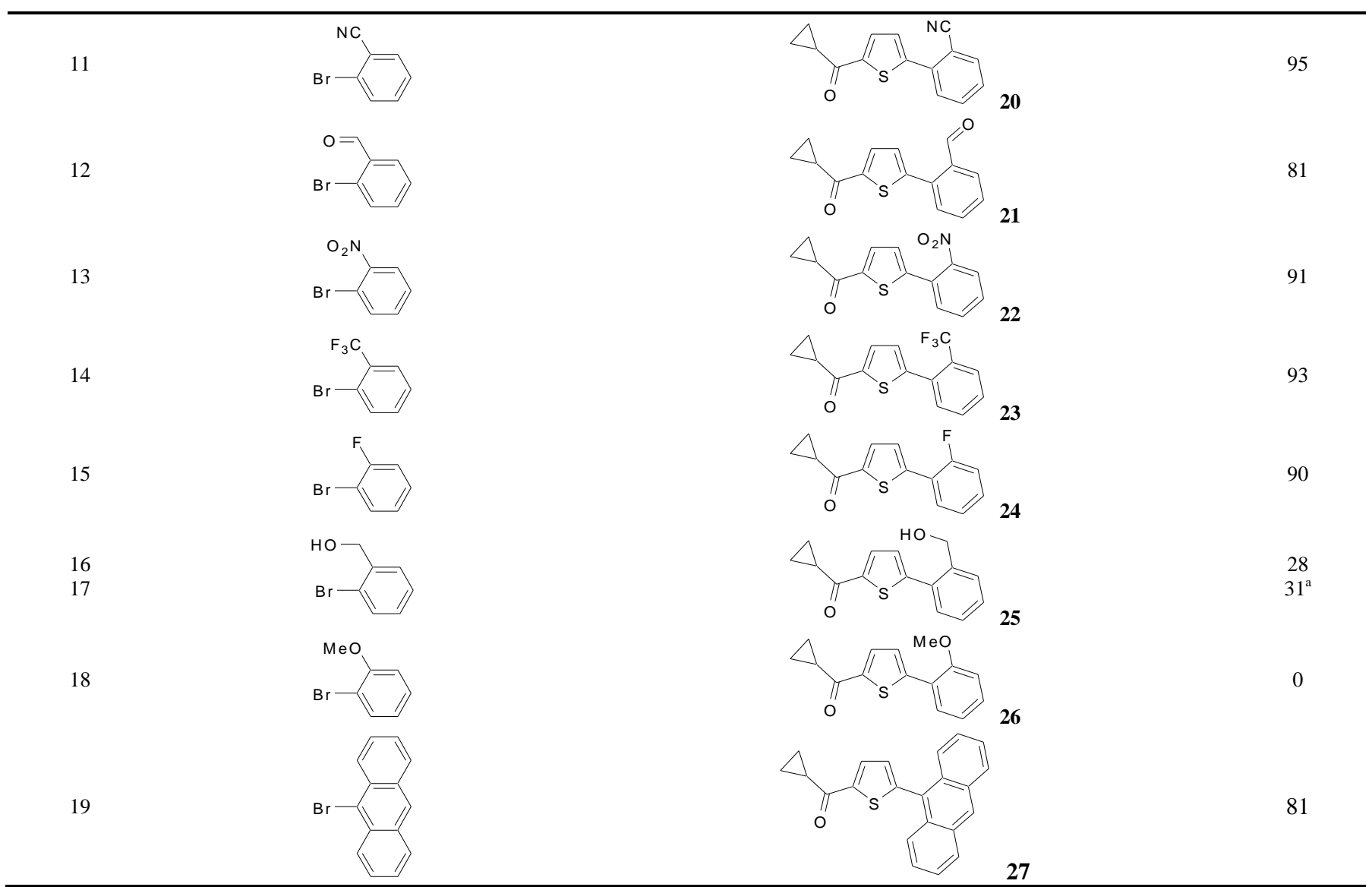

Conditions: $\mathrm{Pd}(\mathrm{OAc})_{2}(0.005 \mathrm{mmol})$, cyclopropyl 2-thienyl ketone $(1.5 \mathrm{mmol})$, aryl bromide $(1 \mathrm{mmol}), \mathrm{KOAc}(2 \mathrm{mmol}), \mathrm{DMA}, 120^{\circ} \mathrm{C}, 16$ h. ${ }^{\text {a }} \mathrm{PdCl}\left(\mathrm{C}_{3} \mathrm{H}_{5}\right)(\mathrm{dppb})(0.02 \mathrm{mmol})$ as the catalyst.

Finally, the reactivity of five heteroaryl bromides for this coupling was examined (Table 4). Pyridines or quinolines are $\pi$ electron deficient heterocycles and therefore, their oxidative addition to palladium is, in general, relatively easy. Using 3bromopyridine, 3-bromoquinoline, 4-bromoisoquinoline or 5-bromopyrimidine, the desired products $\mathbf{2 8}$, 30-32 were obtained in good yields. It should be noted that with 4-bromoisoquinoline, which is quite congested, the use of $2 \mathrm{~mol} \%$ $\mathrm{PdCl}\left(\mathrm{C}_{3} \mathrm{H}_{5}\right)(\mathrm{dppb})$ catalyst at $150^{\circ} \mathrm{C}$ gave a better yield in 31 than $0.5 \mathrm{~mol} \% \mathrm{Pd}(\mathrm{OAc})_{2}$ (table 4 , entries 5 and 6). On the other hand, 2-bromopyridine was found to be unreactive (Table 4, entries 2 and 3). This is probably due to the poisoning of the catalyst by formation of stable palladacycles with this aryl bromide.

Table 4. Palladium-catalysed 5-arylation of cyclopropyl 2-thienyl ketone with heteroaryl bromides (Scheme 2).

Entry




72

Conditions: $\mathrm{Pd}(\mathrm{OAc})_{2}(0.005 \mathrm{mmol})$, cyclopropyl 2-thienyl ketone $(1.5 \mathrm{mmol})$, heteroaryl bromide $(1 \mathrm{mmol}), \mathrm{KOAc}(2 \mathrm{mmol}), \mathrm{DMA}$, $120^{\circ} \mathrm{C}, 16$ h. ${ }^{a} \mathrm{PdCl}\left(\mathrm{C}_{3} \mathrm{H}_{5}\right)(\mathrm{dppb})(0.02 \mathrm{mmol})$ as the catalyst, $150^{\circ} \mathrm{C}$.

In summary, we have demonstrated that using as little as $0.5 \mathrm{~mol} \%$ of $\mathrm{Pd}(\mathrm{OAc})_{2}$ as the catalyst precursor, the 5-arylation via $\mathrm{C}-\mathrm{H}$ bond activation of cyclopropyl 2-thienyl ketone proceeds in moderate to high yields. No significant decomposition of the cyclopropyl ketone group was detected. Moreover, in all cases a completely regioselective reaction in favour of arylation at C5 was observed. This ligand-free procedure gave good results using electron-deficient aryl bromides. By contrast, for electron-rich aryl bromides $\mathrm{PdCl}\left(\mathrm{C}_{3} \mathrm{H}_{5}\right)(\mathrm{dppb})$ catalyst should be preferred. Several functions such as formyl, acetyl, benzoyl, ester, nitro, nitrile, trifluoromethyl, fluoro or methoxy are tolerated on the aryl bromide, and even a congested aryl bromide, such as 9-bromoanthracene, gave a satisfactory result. This ligand-free low catalyst loading procedure is economically and environmentally attractive, as there is no need to eliminate phosphine derivatives at the end of the reaction; and as with this $\mathrm{C}-\mathrm{H}$ bond activation procedure, no preparation of an organometallic derivative is required, reducing the number of steps and therefore the mass of waste products. The major waste is the relatively non-toxic $\mathrm{AcOH} / \mathrm{KBr}$ instead of metallic salts with more classical metal-catalysed coupling reactions. For these reasons, the methodology developed here is very promising for the sustainable synthesis of 5-arylated cyclopropyl 2-thienyl ketones and their derivatives.

\section{Experimental}

\section{General procedure for the preparation of 1-32:}

The reaction of the aryl bromide $(1 \mathrm{mmol})$, cyclopropyl 2-thienyl ketone $(0.228 \mathrm{~g}, 1.5 \mathrm{mmol})$ and $\mathrm{KOAc}(0.196 \mathrm{~g}, 2 \mathrm{mmol})$ at $120^{\circ} \mathrm{C}$ or $150^{\circ} \mathrm{C}$ (see tables) during $16 \mathrm{~h}$ in DMA $(4 \mathrm{~mL})$ in the presence of $\mathrm{Pd}(\mathrm{OAc})_{2}(1.12 \mathrm{mg}, 0.005 \mathrm{mmol})$ or $\mathrm{PdCl}\left(\mathrm{C}_{3} \mathrm{H}_{5}\right)(\mathrm{dppb})(12.2 \mathrm{mg}, 0.02$ mmol) [35] (see tables) under argon affords the coupling product after evaporation of the solvent and purification on silica gel.

\section{References}

[1] E. C. Chao, Drug Fut. 36 (2011) 351-357.

[2] A. Ohta, Y. Akita, T. Ohkuwa, M. Chiba, R. Fukunaga, A. Miyafuji, T. Nakata, N. Tani, Y. Aoyagi, Heterocycles 31 (1990) 1951-1958.

[3] L.-C. Campeau, D. R. Stuart, K. Fagnou, Aldrichim. Acta 40 (2007) 35-41.

[4] B.-J. Li, S.-D. Yang, Z.-J. Shi, Synlett (2008) 949-957.

[5] F. Bellina, R. Rossi, Tetrahedron 65 (2009) 10269-10310.

[6] L. Ackermann, R. Vincente, A. R. Kapdi, Angew. Chem. Int. Ed. 48 (2009) 9792-9826.

[7] X. Chen, K. M. Engle, D.-H. Wang, J.-Q. Yu, Angew. Chem. Int. Ed. 48 (2009) 5094-5115.

[8] J. Roger, A. L. Gottumukkala, H. Doucet, ChemCatChem 2 (2010) 20-40.

[9] J. Wencel-Delord, F. Glorius, Nature Chem. 5 (2013) 369-375.

[10] K. Beydoun, M. Zaarour, J. A. G. Williams, H. Doucet, V. Guerchais, Chem. Commun. 48 (2012) 1260-1262.

[11] K. Beydoun, J. Roger, J. Boixel, H. Le Bozec, V. Guerchais, H. Doucet, Chem. Commun. 48 (2012) 11951-11953.

[12] L. Zhao, C. Bruneau, H. Doucet, Chem. Commun. 49 (2013) 5598-5600.

[13] T. Okazawa, T. Satoh, M. Miura, M. Nomura, J. Am. Chem. Soc. 124 (2002) 5286-5287.

[14] Kobayashi, K.; Sugie, A.; Takahashi, M.; Masui, K.; Mori, A. Org. Lett. 7 (2005) 5083-5085.

[15] Nakano, M.; Tsurugi, H.; Satoh, T.; Miura, M. Org. Lett. 10 (2008) 1851-1854.

[16] Beydoun, K.; Doucet, H. Eur J. Org. Chem. (2012) 6745-6751.

[17] J. J. Li, G. W. Gribble, Palladium in Heterocyclic Chemistry, Pergamon: Amsterdam, 2000.

[18] S. Pivsa-Art, T. Satoh, Y. Kawamura, M. Miura, M. Nomura, Bull. Chem. Soc. Jpn., 71 (1998) 467-473.

[19] L. Lavenot, C. Gozzi, K. Ilg, I. Orlova, V. Penalva, M. Lemaire, J. Organomet. Chem., 567 (1998) 49-55.

[20] K. Masui, H. Ikegami, A.Mori, J. Am. Chem. Soc., 126 (2004) 5074-5075.

[21] J. Roger, F. Pozgan, H. Doucet, Green Chem. 11 (2009) 425-432.

[22] B. Liegault, D. Lapointe, L. Caron, A. Vlassova, K. Fagnou, J. Org. Chem. 74 (2009) 1826-1834.

[23] K. Beydoun, H. Doucet, ChemSusChem 4 (2011) 526-534.

[24] A. Battace, M. Lemhadri, T. Zair, H. Doucet, M. Santelli, Adv. Synth. Catal. 349 (2007) 2507-2516.

[25] S. Rousseaux, B. Liégault, K. Fagnou, Chem. Sci. 3 (2012) 244-248.

[26] M. Wasa, K. S. L. Chan, X.-G. Zhang, J. He, M. Miura, J.-Q. Yu, J. Am. Chem. Soc. 134 (2012) 18570-18572. 
[27] S. Michelliza, A. Al-Mourabit, A. Gateau-Olesker, C. Marazano, J. Org. Chem. 67 (2002) 6474-6478.

[28] S. S. Hall, S. E. Farahat, J. Het. Chem. 24 (1987) 1205-1213.

[29] Y. Yamauchi, G. Onodera, K. Sakata, M. Yuki, Y. Miyake, S. Uemura, Y. Nishibayashi, J. Am. Chem. Soc. 129 (2007) 51755179.

[30] G.-J. Jiang, X.-F. Fu, Q. Li, Z.-X. Yu, Org. Lett. 14 (2012) 692-695.

[31] M. Shi, Y.-H. Yang, B. Xu, Tetrahedron 61 (2005) 1893-1901.

[32] M. Shi, Y.-H. Yang, B. Xu, Synlett (2004) 1622-1624.

[33] T. Tamaki, M. Ohashi, S. Ogoshi, Angew. Chem., Int. Ed. 50 (2011) 12067-12070.

[34] W. Huang, M.-M. O'Donnell, G. Bi, J. Liu, L. Yu, C. M. Baldino, A. S. Bell, T. J. Underwood, Tetrahedron Lett. 45 (2004) 8511-8514.

[35] T. Cantat, E. Génin, C. Giroud, G. Meyer, A. Jutand, J. Organomet. Chem. 687 (2003) 365-376.

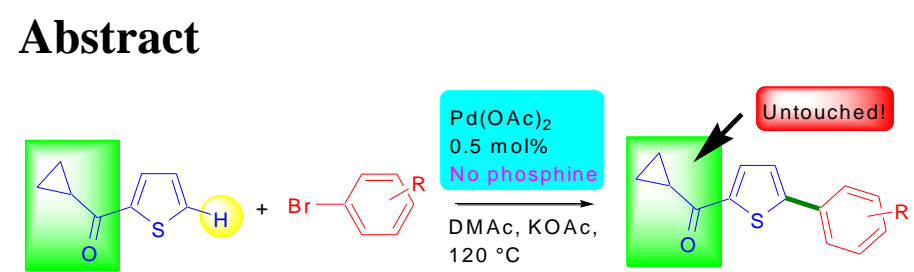

$\mathrm{R}=\mathrm{CN}, \mathrm{CHO}, \mathrm{COMe}, \mathrm{COPh}, \mathrm{CO}_{2} \mathrm{Me}, \mathrm{NO}_{2}, \mathrm{CF}_{3}, \mathrm{~F}, \mathrm{Me}, t \mathrm{Bu}, \mathrm{CH}_{2} \mathrm{OH}, \mathrm{OMe}$ 